\title{
Identification of Chattonella (Raphidophyceae) species in long-term phytoplankton samples from Santa Giusta Lagoon, Italy
}

\author{
Daniela Stacca ${ }^{1}$, Cecilia Teodora Satta ${ }^{1}$, Silvia Casabianca ${ }^{2}$, Antonella Penna ${ }^{2}$, \\ Bachisio Mario Padedda ${ }^{1}$, Nicola Sechi ${ }^{1}$, Antonella Lugliè ${ }^{1}$ \\ ${ }^{1}$ Dipartimento di Architettura, Design e Urbanistica, University of Sassari, Via Piandanna 4, 07100 Sassari, Italy. \\ E-mail: dstacca@uniss.it \\ ${ }^{2}$ Dipartimento di Scienze Biomolecolari, University of Urbino, Viale Trieste 296, 61100 Pesaro, Italy.
}

\begin{abstract}
Chattonella species in a Mediterranean lagoon (Santa Giusta Lagoon, Sardinia, Italy) were identified by applying a molecular approach to fixed natural phytoplankton samples collected over the last two decades. Like the other raphidophytes, Chattonella cells are naked and lose their shape when fixed, making species identification difficult on the basis of their morphological characteristics. Employing species-specific primers (oBTG-005-F, oBTG-027-R, oBTG-028-R) for the amplification of the ITS-5.8S rDNA region, we established the occurrence of $C$. subsalsa in fixed natural phytoplankton samples collected in coincidence with fish death events. Additionally, we established the presence of the recently discovered C. cf. subsalsa Adriatic genotype by analysing cellular cultures obtained from the same lagoon in 2013. This is the second worldwide record of $C$. cf. subsalsa Adriatic genotype. Our results revealed that the species-specific primers oBTG-005-F and oBTG-028-R distinguished this new genotype only when present singularly. This study provides valuable data that increase knowledge of $C$. subsalsa genotypes and of the long-term occurrence of Chattonella blooms in a transitional ecosystem through the use of samples up to 20 years old.
\end{abstract}

Keywords: Chattonella subsalsa genotypes; transitional ecosystems; harmful algal blooms; LTER-Italy; ITS-5.8S rDNA; LSU rDNA.

Identificación de especies de Chattonella (Raphidophyceae) presentes en muestras de fitoplancton recogidas durante un monitoreo de larga duración en la Laguna de Santa Giusta (Cerdeña, Italia)

Resumen: Se identificaron especies de Chattonella mediante la aplicación de técnicas moleculares en muestras naturales de fitoplancton. Las muestras fueron recogidas y fijadas durante las últimas dos décadas en una laguna litoral mediterránea (Laguna de Santa Giusta, Cerdeña, Italia). Al igual que otras rafidoficeas, las células de Chattonella no poseen teca y, por lo tanto, pierden su forma cuando se fijan lo que dificulta la identificación basada en características morfológicas. Con el uso de cebadores específicos a nivel de especie (OBTG-005-F, OBTG-027-R, OBTG-028-R) diseñados para la amplificación de la región ITS- 5.8S rDNA, se detectó la presencia de $C$. subsalsa en las muestras recogidas en periodos coincidentes con eventos de muerte de peces. A través del análisis de los cultivos celulares obtenidos de la misma laguna en el año 2013, se identificó la presencia, por segunda vez a nivel mundial, del recientemente descubierto genotipo Adriático de $C$. cf. subsalsa. Los resultados revelaron que los cebadores oBTG-005-F y oBTG-028-R amplifican este nuevo genotipo sólo cuando está presente individualmente. En este estudio se presentan datos relevantes para el conocimiento de los genotipos de C. subsalsa y sobre la presencia recurrente de proliferaciones de especies de Chatonella en un ecosistema de transición a través de la utilización de muestras recogidas durante los últimos veinte años y analizadas hoy en día.

Palabras clave: genotipos de Chattonella subsalsa; ecosistemas de transición; proliferaciones algales nocivas; LTER-Italia; ITS-5.8S rDNA; LSU rDNA.

Citation/Como citar este artículo: Stacca D., Satta C.T., Casabianca S., Penna A., Padedda B.M., Sechi N., Lugliè A. 2016. Identification of Chattonella (Raphidophyceae) species in long-term phytoplankton samples from Santa Giusta Lagoon, Italy. Sci. Mar. 80(1): 17-25. doi: http://dx.doi.org/10.3989/scimar.04292.09A

Editor: E. Garcés.

Received: June 15, 2015. Accepted: September 8, 2015. Published: December 11, 2015.

Copyright: (c) 2016 CSIC. This is an open-access article distributed under the Creative Commons Attribution-Non Commercial Lisence (by-nc) Spain 3.0. 


\section{INTRODUCTION}

Chattonella Biecheler (Raphidophyceae) exhibits a worldwide distribution and includes deleterious species causing fish kills in natural environments and aquaculture systems (Imai and Yamaguchi 2012 and references therein). The existing Chattonella taxonomy is still debated. Imai and Yamaguchi (2012), in their review, recognized five species: Chattonella antiqua (Hada) Ono, C. marina (Subrahmanyan) Hara et Chihara, $C$. minima Hara et Chihara, C. ovata Hara et Chihara, and C. subsalsa Biecheler. Previously, Demura et al. (2009) had proposed three species, determining that $C$. antiqua and $C$. ovata were varieties of $C$. marina. Recently, a new $C$. cf. subsalsa genotype was discovered in the Mediterranean Sea (Adriatic Sea; Klöpper et al. 2013), and a distinct species was recognized and related to $C$. subsalsa in the Oman Sea, along the southeast coast of Iran (Attaran-Fariman and Bolch 2014).

Like the other raphidophytes, Chattonella species lack rigid cell walls. Consequently, their cellular shape and morphology are lost with fixation (Band-Schmidt et al. 2004, Zingone et al. 2006), making their identification particularly difficult. Instead, molecular techniques enable the identification of Chattonella species, similarly to other raphidophytes, in fixed samples. Moreover, species identification by the molecular approach can be used in retrospective studies (Bowers et al. 2006).

On this basis, the first of our objectives was to identify which Chattonella species had been responsible for past blooms, in a part of the cases (four on five occasions) that coincided with fish kills in a Mediterranean lagoon (Santa Giusta Lagoon, Sardinia). In fact, although Bowers et al. (2006) have already reported C. subsalsa in Santa Giusta Lagoon (Oristano Lagoon Sardinia), we hypothesized that another species, C. marina, might also have been present, due to its

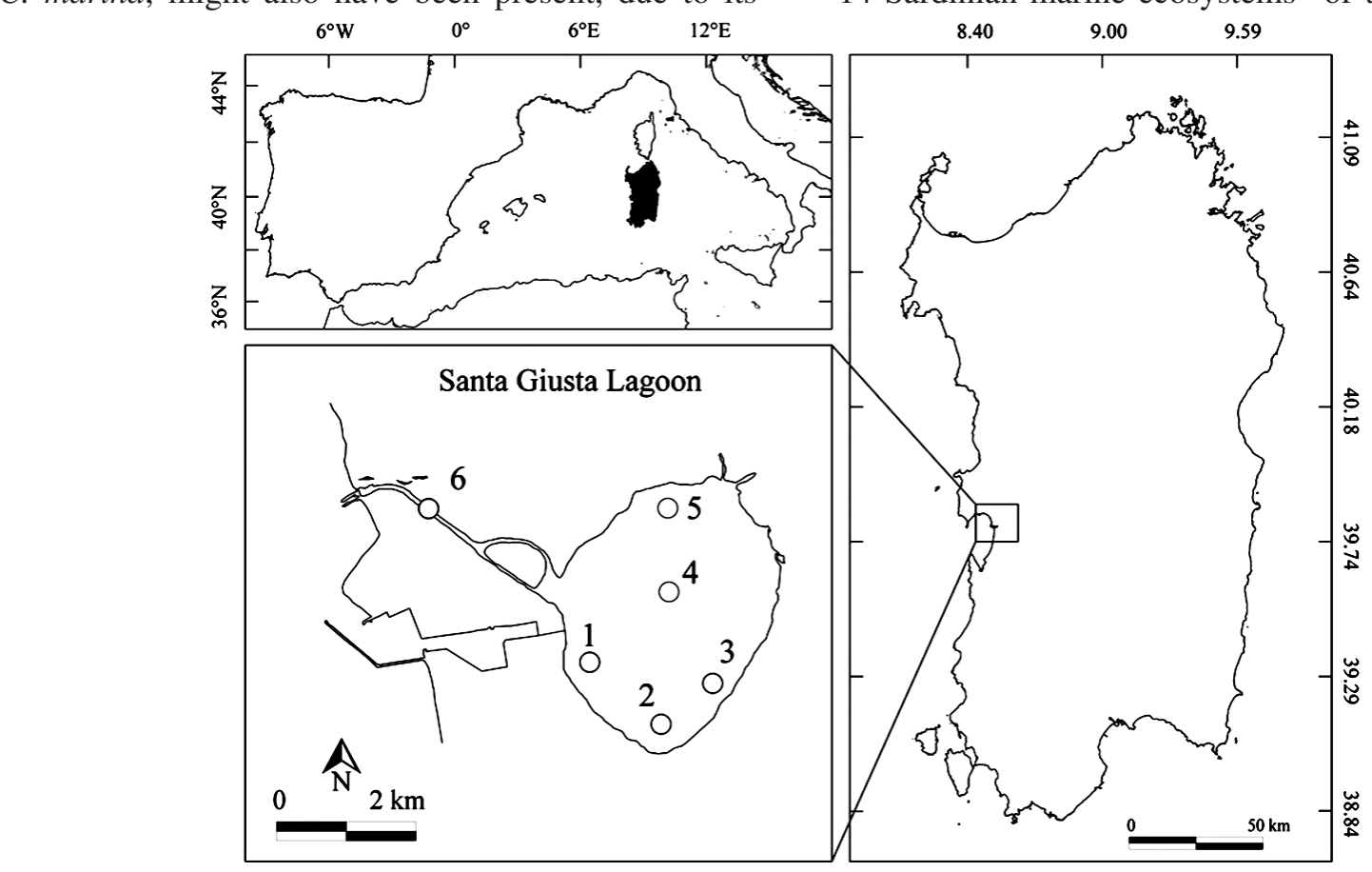

Fig. 1. - Santa Giusta Lagoon and sampling stations. morphological similarity to C. subsalsa and its overt harmfulness for fish (Imai and Yamaguchi 2012 and references therein). Other mass fish and invertebrate mortalities have been attributed to a $C$. antiqua monospecific bloom in the Mediterranean Sea (Alexandria, Egypt; Mikhail 2007).

To achieve our objective, we used a qualitative polymerase chain reaction on archived fixed natural phytoplankton samples (hereinafter named archived samples) up to twenty-years old that were collected during past summer blooms in 1994, 1998, 1999, 2010 and 2013.

Until 2013, as stated above, all strains of C. subsalsa appeared to form a globally homogenous group (hereinafter named Global genotype, Bowers et al. 2006). Clear differences have been reported only recently among strains of the Global genotype and strains from the Adriatic Sea (hereinafter named the Adriatic genotype, Klöpper et al. 2013) and Oman Sea (Attaran-Fariman and Bolch 2014). Since Bowers et al. (2006) identified in Santa Giusta Lagoon C. subsalsa sequences coinciding with the Global genotype and we established the presence of the Adriatic genotype in the same lagoon in 2013, our hypothesis was that both C. subsalsa genotypes might have been present in the analysed archived samples. As a second objective of this study, we wanted to verify whether the same PCRbased assay could discriminate the two genotypes.

\section{MATERIALS AND METHODS}

\section{Study area}

Santa Giusta Lagoon (Italy, western Mediterranean Sea) is located along the west central coast of Sardinia Island (Fig. 1). It is a research station in part of the site "14 Sardinian marine ecosystems" of the LTER-Italy 
Table 1. - List of analysed samples, Chattonella densities and PCR amplification assay results. +, positive amplification; -, negative amplification. * BLD, below the detection limit of $<10$ cells $\mathrm{L}^{-1}$.

\begin{tabular}{|c|c|c|c|c|c|c|}
\hline \multirow{3}{*}{ Sampling date } & \multirow{3}{*}{ Station } & \multirow{3}{*}{$\begin{array}{l}\text { Chattonella density } \\
\quad\left(\text { cells } 10^{3} \mathrm{~L}^{-1}\right)\end{array}$} & \multicolumn{4}{|c|}{ PCR amplifications } \\
\hline & & & \multicolumn{2}{|c|}{ Chattonella subsalsa } & \multicolumn{2}{|c|}{ Chattonella marina } \\
\hline & & & Undiluted DNA & Diluted DNA & Undiluted DNA & Diluted DNA \\
\hline \multirow[t]{2}{*}{$03 / 08 / 1994$} & 1 & 12,927 & --- & +++ & --- & --- \\
\hline & 3 & 30,243 & --- & ++- & --- & --- \\
\hline 25/08/1994 & 5 & 187 & ++- & ++- & --- & --- \\
\hline \multirow[t]{2}{*}{$06 / 09 / 1994$} & 3 & 831 & ++- & ++- & --- & --- \\
\hline & 5 & 256 & ++- & +- & -- & -- \\
\hline \multirow[t]{2}{*}{ 03/09/1998 } & 1 & 179 & +++ & +-- & --- & --- \\
\hline & 5 & 3,249 & +++ & ++- & --- & -- \\
\hline \multirow[t]{2}{*}{ 26/08/1999 } & 2 & 3,692 & ++- & ++- & --- & --- \\
\hline & 3 & 11,931 & ++- & ++- & --- & --- \\
\hline \multirow[t]{2}{*}{ 07/09/1999 } & 1 & 1,278 & -- & ++- & --- & --- \\
\hline & 2 & 1,315 & +-- & +-- & --- & --- \\
\hline \multirow[t]{2}{*}{$19 / 07 / 2010$} & 3 & 399 & ++- & ++- & --- & -- \\
\hline & 5 & 390 & ++- & +- & --- & -- \\
\hline \multirow[t]{3}{*}{$17 / 07 / 2010$} & 6 & BLD* & ++- & --- & --- & -- \\
\hline & 3 & BLD* & --- & --- & --- & --- \\
\hline & 4 & BLD* & -- & --- & --- & --- \\
\hline \multirow{3}{*}{$22 / 07 / 2010$} & 2 & 474 & +++ & ++- & --- & --- \\
\hline & 3 & 2,191 & ++- & +++ & --- & --- \\
\hline & 4 & 584 & ++- & +-- & --- & --- \\
\hline \multirow[t]{2}{*}{$24 / 07 / 2010$} & 1 & 1,600 & +++ & +++ & --- & --- \\
\hline & 3 & 1,827 & ++- & +++ & --- & --- \\
\hline \multirow[t]{2}{*}{$04 / 08 / 2010$} & 2 & 898 & +-- & ++- & --- & --- \\
\hline & 3 & 2,511 & ++- & -- & --- & --- \\
\hline $05 / 04 / 2012$ & 3 & BLD* & -- & -- & -- & -- \\
\hline \multirow[t]{2}{*}{$30 / 07 / 2013$} & 3 & 15 & +++ & +++ & --- & --- \\
\hline & 5 & 34 & +++ & +++ & --- & --- \\
\hline $07 / 08 / 2013$ & 3 & 65 & +++ & +++ & --- & --- \\
\hline
\end{tabular}

network (www.lteritalia.it). Santa Giusta Lagoon has an area of $8 \mathrm{~km}^{2}$ and a mean depth of $1 \mathrm{~m}$. The two primary freshwater inputs are located on the lagoon's east side and sea exchanges are on the western side. Santa Giusta underwent substantial human modification during the last century, resulting in profound ecosystem alterations (Sechi et al. 2001, Lugliè et al. 2002). Sechi et al. (2001) signalled its hypertrophy and reported several fish kill events associated with harmful algal blooms. Moreover, Satta et al. (2014) reported the presence of harmful dinoflagellate cysts in the sediments.

\section{Sampling and phytoplankton analysis}

The 27 archived samples analysed in this study (Table 1) belong to the LTER phytoplankton samples collection maintained at the Dipartimento di Architettura, Design e Urbanistica of the University of Sassari. They were collected from the water surface layer $(-30 \mathrm{~cm})$, from 3 to 5 stations (Fig. 1) during Chattonella blooms in the summers of 1994, 1998, 1999, 2010 and 2013, the first four coinciding with extensive fish mortalities. All samples were immediately fixed with Lugol's iodine solution and analysed within ten days from sampling to assess Chattonella cell densities, following the Utermöhl method (1958) and using an inverted Axiovert Zeiss 25 microscope. Further, within a few hours from the collection, live samples were always observed under the microscope for species identification.

\section{Cellular cultures}

Five clonal cultures of $C$. cf. subsalsa (Adriatic genotype) were established from samples collected from Santa Giusta Lagoon in July 2013 (UNISS7, UNISS8,
UNISS9, UNISS10, UNISS11). Vegetative cells were isolated with glass micropipettes and transferred into IWAKI tissue culture multiplates. Plates were filled with L1 medium (Guillard and Hargraves 1993) prepared with filtered seawater adjusted to a salinity of 35 , and maintained at $20 \pm 1^{\circ} \mathrm{C}$ with a $12: 12$ light:dark cycle. Illumination was provided by a photon irradiance of $100 \mu \mathrm{mol} \mathrm{m} \mathrm{m}^{-2} \mathrm{~s}^{-1}$.

Reference cultures of C. subsalsa (CCMP217; Global genotype) from the Scandinavian Culture Collection of Algae \& Protozoa (SCCAP) and C. antiqua (C. marina var. antiqua, NIES 1) (fixed with Lugol's iodine solution) from the Provasoli-Guillard National Centre for Marine Algae and Micobiota (NCMA, formerly CCMP) were also acquired.

\section{Artificial samples and DNA tests}

Three artificial phytoplankton samples (Lugolfixed, hereinafter named artificial samples) were used to create controlled conditions of presence of Global and Adriatic C. subsalsa genotypes and other algae, as could happen in natural conditions. The first sample contained CCMP217 and UNISS8 strains (sample A; i.e. both Global and Adriatic genotypes), the others only one of the two genotypes, respectively sample $\mathrm{B}$ the Global genotype (CCMP217) and sample $\mathrm{C}$ the Adriatic genotype (UNISS8; Table 2).

Further, we mixed in different proportions the DNA extracted from two different cultures of $C$. subsalsa genotypes (CCMP217 and UNISS8, respectively) by performing six tests (hereinafter named DNA tests, Table 3) to verify whether different DNA concentrations might affect the ITS-5.8S rDNA amplification region. 
Table 2. - Species composition and cell abundances (cells $10^{3} \mathrm{~L}^{-1}$ ) of the analysed artificial samples.

\begin{tabular}{lccc}
\hline & Sample A & Sample B & Sample C \\
\hline C. subsalsa CCMP217 & 816 & 816 & 0 \\
C. cf. subsalsa Adriatic Genotype & 764 & 0 & 764 \\
Alexandrium minutum Halim & 304 & 304 & 304 \\
Amphidinium carterae Hulburt & 550 & 550 & 550 \\
Scrippsiella sp. & 694 & 694 & 694 \\
Cylindrotheca sp. & 490 & 490 & 490 \\
\hline
\end{tabular}

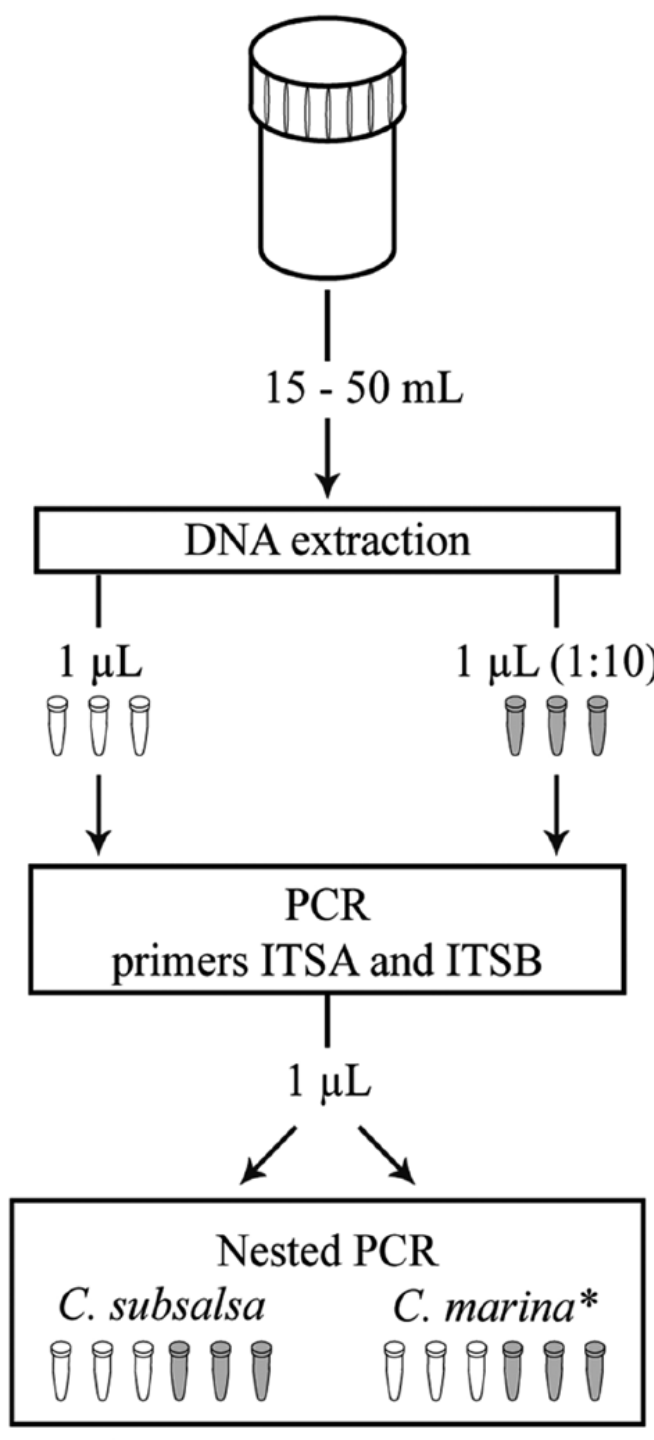

* Only on archived samples or C. marina NIES 1

Fig. 2. - Scheme of the protocol used; in the first passage, $50 \mathrm{~mL}$ of archived samples, $15 \mathrm{~mL}$ of artificial samples or $15 \mathrm{~mL}$ of cultures were used.

\section{Molecular analyses}

DNA was extracted with the DNeasy Plant Kit (Qiagen, Valencia, CA, USA) according to the manufacturer's instructions from $50 \mathrm{~mL}$ of archived samples, artificial samples and from $15 \mathrm{~mL}$ of fixed cultures (Fig. 2).

PCR analyses were performed on archived samples from at least two of the sampled stations for each sampling date (Table 1). An archived sample with $C$. subsalsa abundance below the detection limit $(<10$ cells $\mathrm{L}^{-1}$ ) and from a season not favourable to $C$. $s u b$ salsa growth (Station 3 of 5/4/2012) was used as a negative control. A first PCR was performed with 1 $\mu \mathrm{L}$ of extracted DNA (Fig. 2) in a total of $40.5 \mu \mathrm{L}$ reaction mixture containing the following: $0.25 \mathrm{mM}$ of each dNTP; $0.1 \mu \mathrm{M}$ of each primer; $2.5 \mathrm{mM} \mathrm{MgCl} 2$; 1x HotMaster Taq Buffer (PRIME, Hamburg, Germany); and 2.5 U Taq DNA polymerase (PRIME). ITSA and ITSB primers (Adachi et al. 1994) were used to amplify the internal transcribed spacer (ITS) regions and 5.8S rDNA. PCR conditions were as follows: an initial denaturation step at $94^{\circ} \mathrm{C}$ for $5 \mathrm{~min}$, followed by 35 cycles at $94^{\circ} \mathrm{C}$ for $20 \mathrm{~s}, 57^{\circ} \mathrm{C}$ for $10 \mathrm{~s}$, and $70^{\circ} \mathrm{C}$ for $30 \mathrm{~s}$; and a final elongation step at $70^{\circ} \mathrm{C}$ for $5 \mathrm{~min}$. Six PCR replicates for each sample were performed, three with undiluted DNA and three with 1:10 diluted DNA (Fig. 2). Subsequently, $1 \mu \mathrm{L}$ of each PCR product was used in two distinct nested PCR amplifications (Fig. 2), with the same mixture condition as above. These two different nested PCRs were carried out with specific primers: oBTG-005-F (CTGGGGAAGGATCATTACC) and oBTG-027-R (GCCGATTGCTTCCAGAGA) for C. marina, and oBTG-005-F and oBTG-028-R(CGCCACTCGTTGCCCAGT) for C. subsalsa (Connell 2002). Nested PCR conditions were as follows: an initial denaturation step at $95^{\circ} \mathrm{C}$ for $5 \mathrm{~min}$; then 35 cycles at $95^{\circ} \mathrm{C}$ for $30 \mathrm{~s}, 55^{\circ} \mathrm{C}$ for $10 \mathrm{~s}$ (using species-specific primers for $C$. marina) or $45^{\circ} \mathrm{C}$ for $10 \mathrm{~s}$ (using species-specific primers for $C$. subsalsa), and $72^{\circ} \mathrm{C}$ for $30 \mathrm{~s}$; and a final elongation step at $72^{\circ} \mathrm{C}$ for $10 \mathrm{~min}$. The DNA extracted from the cultures $C$. subsalsa CCMP217 and $C$. antiqua (C. marina var. antiqua) NIES 1 were used as a positive control in each PCR on the analysed archived samples.

Genetic analyses were also conducted to confirm species and genotype identification of the five $C$. cf. subsalsa UNISS7, UNISS8, UNISS9, UNISS10, UNISS11 cultures. For the ITS-5.8S rDNA sequences, the first PCR was performed using ITSA and ITSB primers (Adachi et al. 1994) and the nested PCR with primers oBTG-005-F and oBTG-028-R (Connell 2002), with the same PCR protocol as that described above. PCR primers D1R and D2C (Scholin et al. 1994) were used to amplify the LSU rDNA. PCR was carried out in $50-\mu \mathrm{L}$ reactions containing $1 \mu \mathrm{L}$ of DNA extract, $0.8 \mu \mathrm{M}$ of each primer, $200 \mu \mathrm{M}$ of dNTPs (Qiagen mix), PCR Buffer 1X (Qiagen) containing $1.5 \mathrm{mM}$ of $\mathrm{MgCl}_{2}$, and $1.25 \mathrm{U}$ of Taq DNA polymerase. Thermocycling included one initial step at $95^{\circ} \mathrm{C}$ for $5 \mathrm{~min}$ followed by 40 cycles at $95^{\circ} \mathrm{C}$ for

Table 3. - List of tests carried out using the two C. subsalsa genotypes with different DNA concentrations $\left(\mathrm{ng} \mu \mathrm{L}^{-1}\right)$.

\begin{tabular}{lccc}
\hline & $\begin{array}{c}\text { C. subsalsa } \\
\text { CCMP217 }\end{array}$ & $\begin{array}{c}\text { C. cf. subsalsa } \\
\text { UNISS8 }\end{array}$ & $\begin{array}{c}\text { Concentration } \\
\text { ratio }\end{array}$ \\
\hline TEST 1 & 5.65 & 11.29 & $1: 2$ \\
TEST 2 & 2.26 & 11.29 & $1: 5$ \\
TEST 3 & 1.13 & 11.29 & $1: 10$ \\
TEST 4 & 0.45 & 11.29 & $1: 25$ \\
TEST 5 & 0.26 & 11.29 & $1: 50$ \\
TEST 6 & 0.11 & 11.29 & $1: 100$ \\
\hline
\end{tabular}


Table 4. - ITS-5.8S rDNA sequences obtained in this study and the sequences deposited at GenBank which showed a strong similarity with ours in the BLAST analysis.

\begin{tabular}{llll}
\hline Accession number & Geographical origin & Strain code or source & References \\
\hline AB334367 & Gulf of Mexico, USA & CCMP 217 & Demura et al. 2009 \\
AB334368 & Indian River Bay, USA & CCMP 2191 & Demura et al. 2009 \\
AF153196 & Gulf of Mexico, USA & CCMP 217 & Connell 2000 \\
AF409126 & I & $/$ & Ben Ali et al. 2002 \\
AY858864 & Seto Island Sea, Japan & CMSTAC J04 C. Tomas Japan & Bowers et al. 2006 \\
AY858866 & Salton Sea, California, USA & CMSTAC SS 4 C. Tomas California & Bowers et al. 2006 \\
AY858868 & New River, North Carolina, USA & CMSTAC NR 22 C. Tomas North Carolina & Bowers et al. 2006 \\
AY858869 & Santa Giusta Lagoon, Sardinia, Italy & CMSTAC OL 4 C. Tomas Sardinia & Bowers et al. 2006 \\
DQ191680 & Delaware Inland Bays, USA & CCMP 2191 & Zhang et al. 2006 \\
JF896101 & Iran & CHPI36 & Attaran-Fariman and Bolch 2014 \\
JF907041 & Bahia de Navachiste, Sinaloa, Mexico & CSNAV-1 & Band-Schmidt et al. 2012 \\
JX067584 & Adriatic Sea, Rimini, Italy & CRIM_F & Klöpper et al. 2013 \\
JX067585 & Adriatic Sea, Rimini, Italy & CRIM_E & Klöpper et al. 2013 \\
KR709213 & Santa Giusta Lagoon, Italy & UNISS7 & This study \\
KR709214 & Santa Giusta Lagoon, Italy & UNISS8 & This study \\
KR709215 & Santa Giusta Lagoon, Italy & UNISS9 & This study \\
KR709216 & Santa Giusta Lagoon, Italy & UNISS10 & This study \\
KR709217 & Santa Giusta Lagoon, Italy & UNISS11 & This study \\
KR709218 & Gulf of Mexico, USA & CCMP217 & This study \\
\hline
\end{tabular}

$20 \mathrm{~s}, 55^{\circ} \mathrm{C}$ and at $72^{\circ} \mathrm{C}$ for $1 \mathrm{~min}$, followed by a final extension at $72^{\circ} \mathrm{C}$ for $10 \mathrm{~min}$.

The whole protocol applied on archived samples was also tested on the three artificial samples (Fig. 2, Table 2). The same PCR-based assay was also applied on the six DNA tests (Table 3). The DNA concentration was evaluated with the SmartSpec ${ }^{\mathrm{TM}}$ Plus Spectrophotometer (Bio-rad) following the manufacturer's instruction.

All PCR amplifications were performed in a DNA Engine $^{\circledR}$ Thermal Cycler.

All PCR products were resolved on a 1.8\% (80v) agarose gel. All nested PCR products were purified and sequenced by an external service (Macrogen Inc., Europe) using both primers, and a 3730XL DNA sequencer.
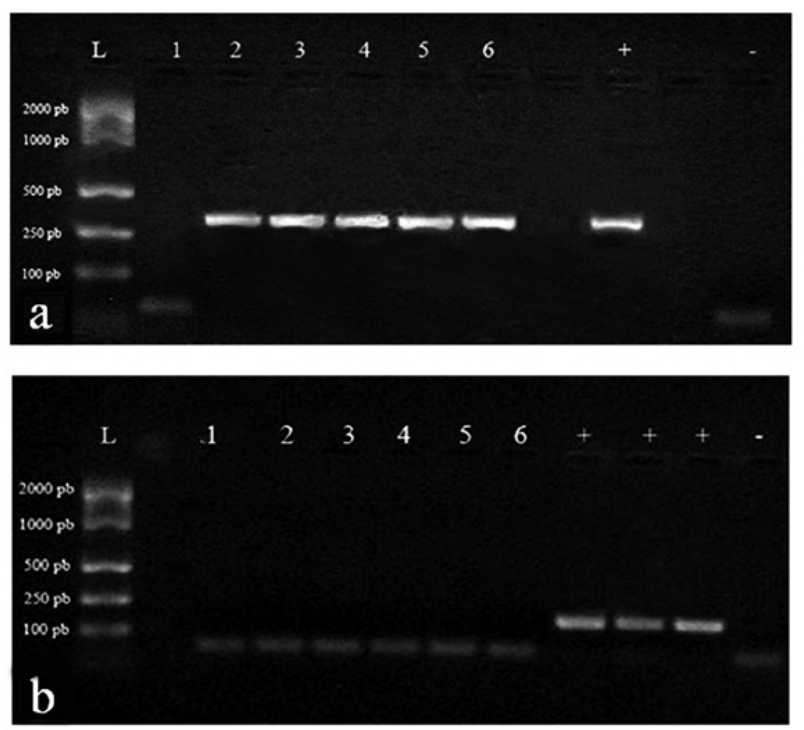

Fig. 3. - Nested PCR amplification products using an EasyLadder I - Bioline (L) for C. subsalsa and C. antiqua (C. marina var. antiqua) NIES 1: a) C. subsalsa, six replicates of 22-7-2010 (station 2) sample with five positive PCR amplifications (2-6), the positive control using CCMP217 culture (+), and the negative control (-); b) C. marina, six replicates of 22-7-2010 (station 3) sample with six negative PCR amplifications (1-6), three replicates of $C$. antiqua (C. marina var. antiqua) NIES 1 culture as positive controls (+), and the negative control (-).

\section{Phylogenetic analyses}

Sequences obtained in this study were compared with sequences in the NCBI Nucleotide Collection (BLAST Algorithm; http://www.ncbi.nlm.-nih.gov) to determine the closest known sequences. Sequences were also aligned with those obtained from GenBank (Table 4 and 5) using the MAFFT v.6 program (Katoh et al. 2002) under FFTNS-i (slow; iterative refinement method). Alignments were manually checked with BioEdit v. 7.0.5 (Hall 1999). Phylogenetic relationships, based on the LSU rDNA data (Table 5), were inferred using maximum likelihood (ML) method and the GTRGAMMA evolution model on Randomized Axelerated Maximum Likelihood v. 7.0.4 $(\mathrm{RA} \times \mathrm{ML})($ Stamatakis 2006). All model parameters were estimated by RA×ML, using Pseudochattonella verruculosa strains from public databases as an outgroup. The tree with the best topology (the one with the greatest likelihood of 1000 alternative trees) was selected by repeated runs on distinct starting trees. Bootstrap ML analysis was done with 1000 pseudo-replicates and the consensus tree was computed with the RA×ML software.

\section{RESULTS}

\section{Archived samples}

Through the sequencing and BLAST analysis of the nested PCR products, C. subsalsa was detected in all archived samples, which resulted positive also for microscope analysis (Table 1 ). The only exception was a sample taken before the beginning of the bloom in 2010 (17/7/2010), for which PCR results were positive and microscope analysis negative, and the sample was assumed as negative (Station 3 of 5/4/2012).

All PCR products unequivocally belonged to $C$. subsalsa, with control DNA of 380 bp length for $C$. subsalsa CCMP217 (Fig 3a, GenBank accession number KR709218) and 181 bp for C. antiqua (C. marina var. antiqua) NIES 1 (Fig 3b).

ITS-5.8S rDNA sequences comparison among sequences from the 24 archived samples and those of C. subsalsa deposited in GenBank (Table 4) yielded a 
Table 5. - List of the species, strains, geographical origin and GenBank accession numbers of species used in the LSU rDNA phylogenetic tree. * obtained in this study.

\begin{tabular}{|c|c|c|c|}
\hline Species & Strain code or source & Geographical origin & $\begin{array}{l}\text { Accession } \\
\text { Number }\end{array}$ \\
\hline \multirow{5}{*}{ Fibrocapsa cf. japonica } & FRIM_A & Adriatic Sea, Rimini, Italy & JX067577 \\
\hline & FRIM_B & Adriatic Sea, Rimini, Italy & JX067578 \\
\hline & FRIM_C & Adriatic Sea, Rimini, Italy & JX067574 \\
\hline & FRIM_D & Adriatic Sea, Rimini, Italy & JX067575 \\
\hline & FRIM_E & Adriatic Sea, Rimini, Italy & JX067576 \\
\hline F. japonica & CCMP1661 & Port Phillip Bay, Australia & JX067580 \\
\hline \multirow[t]{2}{*}{ Toriumi et Takano } & Fibjap_JG & North Sea, Germany: & JX067579 \\
\hline & LB2162 & / & AF086949 \\
\hline Haramonas dimorpha Horiguchi 1996 & CCMP2053 & Queensland, Australia & JX067581 \\
\hline Heterosigma akashiwo (Hada) & NIES-145 & Kagoshima, Japan & $\mathrm{AB} 217645$ \\
\hline \multirow{4}{*}{ Hada ex Hara et Chihara } & 893 & / & AB217646 \\
\hline & OS-11 & / & AB2 17647 \\
\hline & 1 & Korea & JX067554 \\
\hline & CCMP2274 & California, USA & JX067555 \\
\hline \multirow[t]{4}{*}{ C. subsalsa Biecheler } & 1 & / & AF409126 \\
\hline & CCMP217 & Gulf of Mexico, USA & JX067559 \\
\hline & CCMP217 & Gulf of Mexico, USA & AF210736 \\
\hline & CCMP217 & Gulf of Mexico, USA & KR709212* \\
\hline C. cf. subsalsa & CHPI36 & Iran & JF896100 \\
\hline \multirow{20}{*}{ C. cf. subsalsa Adriatic } & R281 & Gulf of Naples, Italy & JN390438 \\
\hline & CRIM_A & Rimini, Adriatic, Italy & JX067560 \\
\hline & CRIM_B & Rimini, Adriatic, Italy & JX067562 \\
\hline & CRIM_C & Rimini, Adriatic, Italy & JX067568 \\
\hline & CRIM_D & Rimini, Adriatic, Italy & JX067564 \\
\hline & CRIM_E & Rimini, Adriatic, Italy & JX067567 \\
\hline & CRIM_F & Rimini, Adriatic, Italy & JX067563 \\
\hline & CRIM_G & Rimini, Adriatic, Italy & JX067572 \\
\hline & CRIM_H & Rimini, Adriatic, Italy & JX067561 \\
\hline & CRIM_I & Rimini, Adriatic, Italy & JX067571 \\
\hline & CRIM_J & Rimini, Adriatic, Italy & JX067570 \\
\hline & CRIM_K & Rimini, Adriatic, Italy & JX067565 \\
\hline & CRIM_L & Rimini, Adriatic, Italy & JX067566 \\
\hline & CRIM_M & Rimini, Adriatic, Italy & JX067569 \\
\hline & CRIM_N & Rimini, Adriatic, Italy & JX067573 \\
\hline & UNISS7 & Santa Giusta Lagoon, Italy & KR709207* \\
\hline & UNISS8 & Santa Giusta Lagoon, Italy & KR709208* \\
\hline & UNISS9 & Santa Giusta Lagoon, Italy & KR709209* \\
\hline & UNISS10 & Santa Giusta Lagoon, Italy & KR709210* \\
\hline & UNISS11 & Santa Giusta Lagoon, Italy & KR709211* \\
\hline Chattonella marina var. antiqua (Hada) Demura & CCMP2052 & Aichi, Japan & JX067556 \\
\hline \multirow[t]{6}{*}{ \& Kawachi, comb et stat. nov. } & G8 & / & AB217634 \\
\hline & NIES-1 & Harima-Nada, Japan & AB217631 \\
\hline & NIES-1 & Harima-Nada, Japan & AF210737 \\
\hline & NIES-558 & Mikawa Bay, Japan & $\mathrm{AB} 217632$ \\
\hline & NIES-86 & Uranouchi Bay, Japan & AB217868 \\
\hline & OA-3 & / & AB217633 \\
\hline C. marina var. marina & S-11 & / & AB217637 \\
\hline \multirow{7}{*}{ Chihara } & NIES-559 & Maizuru Bay, Japan & AB217636 \\
\hline & G-12 & / & AB217638 \\
\hline & MS-3-P & / & AB217639 \\
\hline & NIES-121 & Kagoshima Bay, Japan & AB2 17635 \\
\hline & 1 & Hong Kong & AY704162 \\
\hline & CCMP-217 & 1 & AF210739 \\
\hline & CCMP2049 & Kagoshima, Japan & JX067557 \\
\hline Chattonella marina var. ovata (Y. Hara \& Chi- & NIES-603 & Harima-Nada, Japan & AB217640 \\
\hline \multirow[t]{3}{*}{ hara) Demura \& Kawachi, comb. et stat. nov. } & ovata-P & / & AB217641 \\
\hline & / & Hong Kong & AY704163 \\
\hline & NIES-603 & Harima-Nada, Japan & AF210738 \\
\hline Pseudochattonella verruculosa & NIES 670 & Harima-Nada, Japan & AM040504 \\
\hline \multirow[t]{2}{*}{ Hosoi-Tanabe 2007} & NIES-670 & Harima-Nada, Japan & AB217642 \\
\hline & ver-P & / & AB217643 \\
\hline
\end{tabular}

BLAST analysis with a 99\%-100\% similarity with the Global genotype sequences, 96\%-97\% sequence identity with the $C$. cf. subsalsa strains CRIM E and CRIM F (i.e. Adriatic genotype) and 98\%-99\% sequence identity with the $C$. cf. subsalsa strain CHPI36.

\section{Cellular cultures}

The nested PCR on cellular cultures produced six ITS-5.8S rDNA sequences (Table 4), four of which were of 573 bp (UNISS7, UNISS8, UNISS9, UNISS10 strains) and one of $576 \mathrm{pb}$ (UNISS11 strain). These five sequences were longer than the nested PCR product of CCMP217 strain (380 pb) (Fig. 4).

The MAFT alignment among the oBTG-028-R primer and the ITS-5.8S rDNA sequences of $C$. $s u b$ salsa strains (UNISS7, UNISS9, CCMP217, CRIM E and C. Tomas Sardinia) indicated seven differences for UNISS7, UNISS9, CRIM E strains (i.e. Adriatic genotype) with respect to the CCMP217 and C. Tomas Sar- 


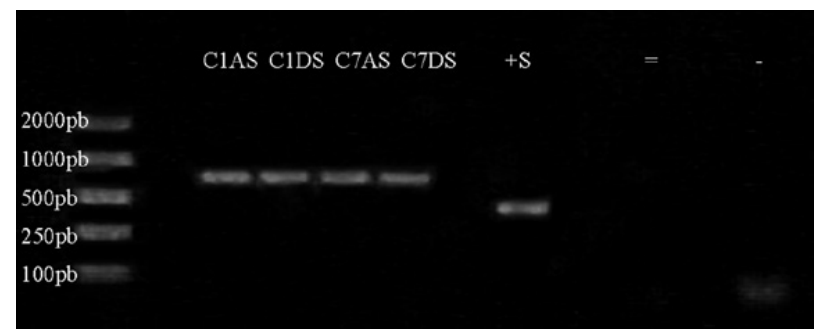

Fig. 4. - Nested PCR amplification products using an EasyLadder I - Bioline (L) for $C$. cf. subsalsa Adriatic genotype (where C1AS, C1DS are the UNISS7 strain and C7AS, C7DS are the UNISS11 strain), C. subsalsa CCMP217 culture (+S), and two negative controls $(=,-)$.

dinia strains (i.e. Global genotype). The BLAST analysis of 5.8S-ITS rDNA sequences showed a 99\%-100\% similarity of UNISS7, UNISS8, UNISS9, UNISS10 and UNISS11 strains with $C$. cf. subsalsa CRIM E and CRIM F strains and 94\%-96\% sequence identity with all C. subsalsa Global sequences (Table 4).

The six LSU rDNA partial sequences were long $652 \mathrm{pb}$ for UNISS7, $650 \mathrm{pb}$ for UNISS8, UNISS10 and UNISS11, $651 \mathrm{pb}$ for UNISS9 and $643 \mathrm{pb}$ for CCMP217. The ML phylogenetic tree obtained for LSU rDNA sequences showed that $C$. subsalsa strains divided into two distinct groups (Fig. 5). The first group showed a branch with the only $C$. cf. subsalsa
CHPI36 and another with C. subsalsa CCMP217 and C. subsalsa AF409126. The second group included all C. cf. subsalsa Adriatic genotype (Klöpper et al. 2013) and UNISS7, UNISS8, UNISS9, UNISS10, UNISS11 strains, with a bootstrap value of $100 \%$. All strains of C. marina var. marina, C. marina var. ovata, and $C$. marina var. antiqua grouped together with a $100 \%$ bootstrap support.

\section{Artificial samples and DNA tests}

The nested PCR of the samples A and B produced sequences with a length of $380 \mathrm{pb}$ belonging to $C$. subsalsa CCMP217. The nested PCR of sample C produced a sequence with a length of 573 pb belonging to C. cf. subsalsa UNISS8.

The nested PCR of DNA tests produced sequences with a length of $380 \mathrm{pb}$ belonging to the CCMP217 strain even when $C$. cf. subsalsa UNISS8 had a concentration one hundred times higher.

\section{DISCUSSION}

Chattonella is one of the raphidophyte genera which includes species associated with fish kills (Hallegraeff and Hara 2003). The searching out of these taxa in recent investigations and in time series data has

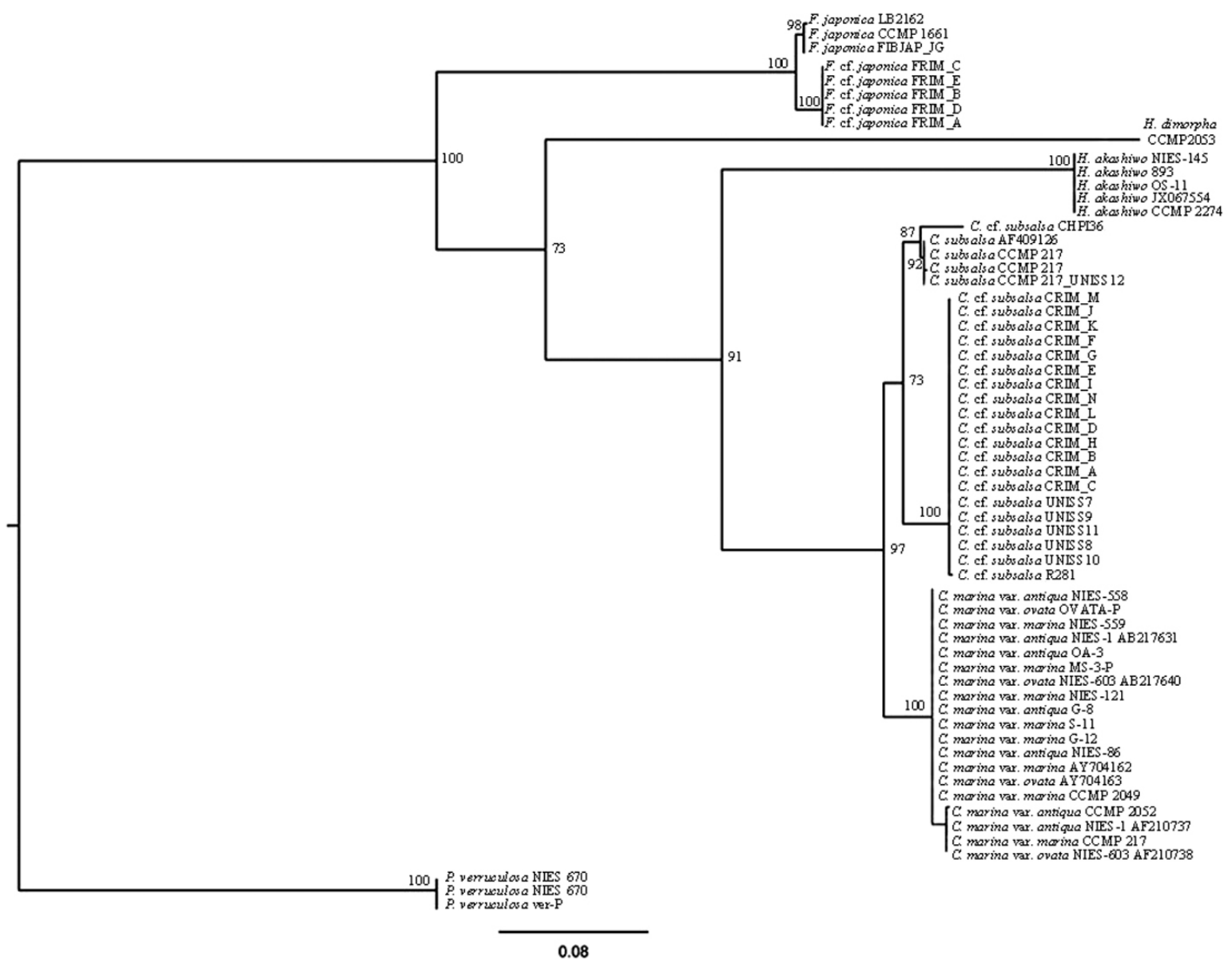

Fig.5. - Maximum likelihood (ML) phylogenetic tree of LSU rDNA sequences among Chattonella-like species. C. subsalsa CCMP217 UNISS12 is the sequence obtained in this study for the C. subsalsa Global genotype (KR709212), Pseudochattonella verruculosa strains from public databases were used as an outgroup. Bootstrap values $(>70 \%)$ are shown respectively at each node. 
been very difficult due to the loss of necessary morphological characteristics in fixed samples (Klöpper et al. 2013), and presumably due to low cell abundance in coastal areas (Imai et al. 2006). Consequently, Chattonella species often become evident only when harmful events occur. Further, whereas harmful Chattonella blooms have been well documented on East Asian coasts, i.e. those of Japan, Korea (Kim et al. 2007), China (Tseng et al. 1993), India (Subrahmanyan 1954, Jugnu and Kripa 2009), South Australia (Hallegraeff et al. 1998), and southeast USA (California,Tomas 1998, Lewitus et al. 2008), in the last few decades (Imai and Yamaguchi 2012) they have been less frequently reported from Mediterranean coastal areas, including lagoons and other transitional ecosystems (Mikhail 2007). The use of molecular methods to detect the presence of Chattonella species is a viable alternative approach to expedite and facilitate identification in fixed natural samples (Connell 2002, Bowers et al. 2006; Marin and Scholin 2010), as has been experienced for other harmful species (Penna et al. 2007).

Between $C$. marina and $C$. subsalsa, the former is the most notorious fish-killing species and has caused severe damage to fish farming and wild fish populations, with great economic losses (Imai and Yamaguchi 2012). C. subsalsa has exhibited relatively more recent history as a deleterious species, and data on this species is scarce (Imai and Yamaguchi 2012). Cell morphology shows overlapping characters between $C$. subsalsa and $C$. marina, as emphasized by Hallegraeff and Hara (2003). Consequently, species identification with microscopic methods is uncertain, especially on fixed samples, whereas molecular techniques appear useful for obtaining valuable results.

Bowers et al. (2006) have already reported $C$. subsalsa in Santa Giusta Lagoon, analysing a strain obtained from a non-bloom sample (Lugliè A., personal communication). Our study considered a longer and more detailed temporal scale in the same Mediterranean lagoon and documented the presence of $C$. $s u b$ salsa also during four past harmful events coinciding with fish kills $(1994,1998,1999,2010)$, and a bloom in 2013 (cells density up to $6510^{3} \mathrm{~L}^{-1}$ ). The use of molecular investigative techniques on archived samples collected over time up to 20 years old allowed us to identify unequivocally the species and helped increase knowledge of C. subsalsa in the Mediterranean Sea. Indeed, this geographical area is not yet well documented for this species, though its type locality is a Mediterranean lagoon (Thau Lagoon, Salins de Villeroy, Sète; Biecheler 1936). Although we cannot support a causeeffect relationship between $C$. subsalsa blooms and fish kills, which have been observed concurrently over the years, our results can confirm that when harmful events occurred, C. subsalsa was present. On-going studies integrating our long-term ecological data will offer further detailed scenarios on the environmental conditions accompanying these events.

A further new knowledge that emerged from our results was the presence of the $C$. cf. subsalsa Adriatic genotype in the Santa Giusta Lagoon, thanks to the analyses on the cultures obtained in 2013. This is the first unequivocal evidence of this genotype in a Mediterranean lagoon and in a different place to those of its first ascertainment (Klöpper et al. 2013). The analyses performed to assess whether both genotypes had been present in the archived samples could not resolve the question. In fact, the positive results of the PCR only for $C$. subsalsa Global genotype in the archived samples, artificial samples A and B and DNA tests could be explained because of the differences in the DNA bases of the two $C$. subsalsa genotypes where the oBTG028-R primer binds. This is a specific primer constructed by Connell (2002) for C. subsalsa CCMP217 Global genotype. The length of $C$. subsalsa Global genotype sequences obtained in this study was in accordance with Connell (2002), whereas C. cf. subsalsa Adriatic genotype sequences were longer, indicating a different primer response. Therefore, this primer cannot discriminate the two $C$. subsalsa genotypes when they are present at the same time. On this basis, because of the positivity of $C$. subsalsa Global genotype in all archived samples, we cannot state whether the blooms were due to the contemporaneous presence of both the genotypes. However, for the same reason, we can state that none of them was due only to the $C$. cf. subsalsa Adriatic genotype.

In conclusion, our results support the recent studies of Klöpper et al. (2013) and Attaran-Fariman and Bolch (2014), highlighting the existence of clearly distinct strains of $C$. subsalsa. We also support the "overlapping hypothesis" of the two genotypes, Adriatic and Global, in the same geographical area (Klöpper et al. 2013). In fact, in addition to our assessment of the $C$. cf. subsalsa Adriatic genotype in Santa Giusta Lagoon and the previous record of the C. subsalsa Global genotype at the same site (Bowers et al. 2006), we also confirm the presence of the Global genotype along the western Sardinian coasts (Bosa beach; data not published).

The need for further studies is evident, using a plurality of markers on strains from additional Mediterranean and world sites, in order to ascertain the possibility of different new species.

\section{ACKNOWLEDGEMENTS}

This study was produced as part of the $\mathrm{PhD}$ dissertation in Environmental Biology from the University of Sassari, Academic year 2010-2011 - 26th cycle, with the support of a grant funded with resources from the POR SARDINIA F.S.E. 2007-2013 - Objective Regional Competitiveness and Employment, Human Capital Priority IV, Line Operation 1.3.1. The authors thank Adriana Zingone of the Laboratory of Marine Botany, Stazione Zoologica “A. Dohrn”, Napoli, Italy for her support and advice on the analyses.

\section{REFERENCES}

Adachi M., Sako Y., Ishida Y. 1994. Restriction fragment length polymorphism of ribosomal DNA internal transcribed spacer and 5.8S regions in Japanese Alexandrium species (Dinophyceae). J. Phycol. 30: 857-863. http://dx.doi.org/10.1111/j.0022-3646.1994.00857.x 
Attaran-Fariman G., Bolch C.J.S. 2014. Morphology and genetic affinities of a novel Chattonella isolate (Raphidophyceae) isolated from Iran's south coast (Oman Sea). Turk. J. Bot. 38: 156-168. http://dx.doi.org/10.3906/bot-1210-33

Band-Schmidt C.J., Morquecho L., Hernandez-Becerril D.U., et al. 2004. Raphidophyceans on the coasts of Mexico. Hydrobiologia 515: 79-89. http://dx.doi.org/10.1023/B:HYDR.0000027320.00977.8b

Band-Schmidt C.J., Martínez-López A., Bustillos-Guzmán J.J., et al. 2012. Morphology, biochemistry, and growth of raphidophyte strains from the Gulf of California. Hydrobiologia 693: 81-97. http://dx.doi.org/10.1007/s10750-012-1088-y

Ben Ali A., De Baere R., De Wachter R., et al. 2002. Evolutionary relationships among heterokont algae (the autotrophic stramenopiles) based on combined analyses of small and large subunit ribosomal RNA. Protist 153(2): 123-132. http://dx.doi.org/10.1078/1434-4610-00091

Biecheler B. 1936. Sur une Chloromonadine nouvelle d'eau saumatre Chattonella subsalsa n. gen., n. sp. Arch. Zool. Exp. Gen. 78: $79-83$.

Bowers H., Tomas C., Tengs T., et al. 2006. Raphidophyceae [Chadefaud ex Silva] systematics and rapid identification: sequence analyses and real-time PCR assays. J. Phycol. 42: 1333-1348. http://dx.doi.org/10.1111/j.1529-8817.2006.00285.x

Connell L.B. 2000. Nuclear ITS region of the alga Heterosigma akashiwo (Chromophyta: Raphidophyceae) is identical in isolates from Atlantic and Pacific basins. Mar. Biol. 136: 953-960. http://dx.doi.org/10.1007/s002270000314

Connell L. 2002. Rapid identification of marine algae (Raphidophyceae) using three-primer PCR amplification of nuclear internal transcribed spacer (ITS) regions from fresh and archived material. Phycologia 41(1): 15-21. http://dx.doi.org/10.2216/i0031-8884-41-1-15.1

Demura M., Noël M.H., Kasai F., et al. 2009. Taxonomic revision of Chattonella antiqua, C. marina and C. ovata (Raphidophyceae) based on their morphological characteristics and genetic diversity. Phycologia 48(6): 518-535. http://dx.doi.org/10.2216/08-98.1

Guillard R.R.L., Hargraves P.E. 1993. Stichochrysis immobilis is a diatom, not a chrysophyte. Phycologia 32(3): 234-236. http://dx.doi.org/10.2216/i0031-8884-32-3-234.1

Hall T.A. 1999. BioEdit: a user-friendly biological sequence alignment editor and analysis program for Windows 95/98/NT. Nucl. Acid. S. 41: 95-98.

Hallegraeff G.M., Hara Y. 2003. Taxonomy of harmful marine raphidophytes. In: Hallegraeff G.M., Anderson D.M., Cembella A.D. (eds), Manual on harmful marine microalgae. Monographs on Oceanographic Methodology. Methodology 11, Unesco Paris, pp. 511-522.

Hallegraeff G.M., Munday B., Baden D., et al. 1998. Chattonella marina (Raphidophyte) bloom associated with mortality of cultured bluefin tuna (Thunnus maccoyii) in south Australia. In: Reguera B., Blanco J., Fernandez M.L., et al. (eds), Harmful Algae. Xunta de Galicia and IOC-UNESCO, Vigo, Paris, pp. 93-96.

Imai I., Yamaguchi M., Hori Y. 2006. Eutrophication and occurrences of harmful algal blooms in the Seto Inland Sea. Plank. Benth. Res. 1: 71-84 http://dx.doi.org/10.3800/pbr.1.7

Imai I., Yamaguchi M. 2012. Life cycle, physiology, ecology and red tide occurrences of the fish-killing raphidophyte Chattonella. Harmful Algae 14: 46-70. http://dx.doi.org/10.1016/j.hal.2011.10.014

Jugnu R., Kripa V. 2009. Effect of Chattonella marina [(Subrahmanyan) Hara et Chihara 1982] bloom on the coastal fishery resources along Kerala coast, India. Indian J. Mar. Sci. 38: 77-88.

Katoh K., Misawa K., Kuma K., et al. 2002. MAFFT: a novel method for rapid multiple sequence alignment based on fast Fourier transform. Nucleic Acids Res. 30(14): 3059-3066. http://dx.doi.org/10.1093/nar/gkf436
Kim S.Y., Seo K.S., Lee C.K., et al. 2007. Diurnal modification of a red tide causing organisms, Chattonella antiqua (Raphidophyceae) from Korea. Algae 22: 95-106. http://dx.doi.org/10.4490/ALGAE.2007.22.2.095

Klöpper S., John U., Zingone A., et al. 2013. Phylogeny and morphology of a Chattonella (Raphidophyceae) species from the Mediterranean Sea: what is C. subsalsa? Eur. J. Phycol. 48(1):79-92. http://dx.doi.org/10.1080/09670262.2013.771412

Lewitus A.J., Brock L.M., Burke M.K., et al. 2008. Lagoonal stormwater detention ponds as promoters of harmful algal blooms and eutrophication along the South Carolina coast. Harmful Algae 8: 60-65. http://dx.doi.org/10.1016/j.hal.2008.08.012

Lugliè A., Sechi N., Oggiano G., et al. 2002. Ecological assessment of Santa Giusta Lagoon (Sardinia, Italy). Ann. Chim-Rome 92: 239-247.

Marin III R., Scholin C. 2010. Sandwich Hybridization. In: Karlson B., Cusack C., Bresnan E. (eds), Microscopic and molecular methods for quantitative phytoplankton analysis. IOC Man Guides 55, Unesco Paris, pp 87-110.

Mikhail S.K. 2007. First monospecific bloom of the harmful raphidophyte Chattonella antiqua (Hada) Ono in Alexandria waters related to water quality and copepod grazing. Chem. Ecol. 23(5): 393-407. http://dx.doi.org/10.1080/02757540701587657

Penna A., Bertozzini E., Battocchi C., et al. 2007. Monitoring of HAB species in the Mediterranean Sea through molecular techniques. J. Plankton Res. 29: 19-38. http://dx.doi.org/10.1093/plankt/fb1053

Satta C.T., Anglès S., Garcès E., et al. 2014. Dinoflagellate cyst assemblages in surface sediments from three shallow Mediterranean Lagoons (Sardinia, North Western Mediterranean Sea). Estuar. Coasts 37: 646-663. http://dx.doi.org/10.1007/s12237-013-9705-1

Scholin C.A., Herzog M., Sogin M., et al. 1994. Identification of group and strain-specific genetic markers for globally distributed Alexandrium (Dinophyceae). 2. Sequence analysis of a fragment of the LSU rRNA gene. J. Phycol. 30(6): 999-1011. http://dx.doi.org/10.1111/j.0022-3646.1994.00999.x

Sechi N., Fiocca F., Sannio A., et al. 2001. Santa Giusta Lagoon (Sardinia): phytoplankton and nutrients before and after waste water diversion. J. Limnol. 60(2): 194-200. http://dx.doi.org/10.4081/jlimnol.2001.1.194

Stamatakis A. 2006. RAxML-VI-HPC: Maximum Likelihoodbased Phylogenetic Analyses with Thousands of Taxa and Mixed Models. Bioinformatics 22(21): 2688-2690. http://dx.doi.org/10.1093/bioinformatics/btl446

Subrahmanyan R. 1954. On the life-history and ecology of Hornellia marina gen. et sp. nov., (Chloromonadineae), causing green discoloration of the sea and mortality among marine organisms off the Malabar Coast. Indian J. Fish. 1: 182-203.

Tomas C. 1998. Blooms of potentially harmful raphidophycean flagellates in Florida coastal waters. In: Reguera B., Blanco J., Fernandez M.L., et al. (eds), Harmful Algae. Xunta de Galicia and IOC-UNESCO, pp. 101-103.

Tseng C.K., Zhou M.J., Zou J.Z. 1993. Toxic phytoplankton studies in China. In: Smayda T.J., Shimizu Y. (eds), Toxic Phytoplankton Blooms in the Sea. Elsevier, New York, pp. 347-352.

Utermöhl H. 1958. Zur vervollkommung der quantitativen phytoplankton-methodik. Verkandlungen der Internationalen Vereinigung für Theoretische und Angewandte, Limnol. 9: 1-39.

Zhang Y., Fu F.-X., Whereat E., Coyne K.J., Hutchins D.A. 2006. Bottom-up controls on a mixed-species HAB assemblage: A comparison of sympatric Chattonella subsalsa and Heterosigma akashiwo (Raphidophyceae) isolates from the Delaware Inland Bays. Harmful Algae 5: 310-320. http://dx.doi.org/10.1016/j.hal.2005.09.001

Zingone A., Siano R., D’Alelio D., et al. 2006. Potentially toxic and harmful microalgae from coastal waters of the Campania region (Tyrrhenian Sea, Mediterranean Sea). Harmful Algae 5: 321-337. http://dx.doi.org/10.1016/j.hal.2005.09.002 